\title{
Addictive and Substractive Combined Production of Cobalt-Crome-Based Frames in Dentistry
}

\author{
Kónya János, ${ }^{1}$ Kulcsár Klaudia ${ }^{2}$ \\ Dent-Art-Technik Kft., Györ, Hungary \\ ${ }^{1}$ janos@dentarttechnik.hu \\ ${ }^{2}$ kulcsar.klaudia@dentarttechnik.hu
}

\begin{abstract}
The following study analyses the use of modern 3D printing technology in dentistry with its necessary manufacturing and machining processes. Fitting of the manufactured metal structures is examined depending on their use, in terms of conventional adhesion-based denture designs and screw-fixed dentures on implants. Influencing factors and effects of the required post-processing steps are examined. Aspects such as sand-blasting, heat treatment, equipment and tools required for cutting are analyzed. The aim of this study is to create a manufacturing process that enables the required precision fitting of the created frame structure types.
\end{abstract}

Keywords: additive manufacturing, $3 D$ printing, $C N C$ milling, print and mill, CoCr frame structure.

\section{Introduction}

The possibility of the technological use of 3D printing and the penetration of this technology in dental practice make it indispensable to study the increasingly precise and accurate fitting of metal frame structures in a necessary and sufficient way $[1,2]$. Cases presented in this study were analyzed after the execution of concrete work projects. Fitting evaluation tests were carried out using in vitro models in our dental technician laboratory. Oral in vivo tests were carried out in a medical environment. The aim of this study was to analyze the surface characteristics of additively manufactured metal structures. A great emphasis was put on the factors affecting nesting precision, such as support structures, surface roughness in different directions and positions, and other deviations $[3,4,13]$. Thus, the compensation of the virtual design before printing, the potential printing adjustment, and the necessity of subtractive processes arising from the function and fixation of the frame structure could be determined $[5,6]$.

\section{The process of $3 \mathrm{D}$ printing}

\subsection{Material}

During additive manufacturing, the dental Co$\mathrm{Cr}$ alloy is used as the material of structural frames for dental prostheses $[3,7,8]$.

Manufacturer: BEGO, type: Mediloy S-Co, 5, ISO 22674 and ISO 9693-1. Chemical composition: Co63.9 Cr24.7 W5.4 Mo5.0 Si1.0 (\%) grain size: $10-45 \mu \mathrm{m}$.

\subsection{Sisma MySint 100 and the process of me- tal-powder printing}

A Sisma MySint100 printing unit, using LMF (Laser Metal Fusion) technology, was used for our experiments. During printing, additive and systematic layer-by-layer fusion of $20 \mu \mathrm{m}$-thick metal powder particles takes place (Figure 1.). Fusion is achieved by using a scanning laser with a focal point of $55 \mu \mathrm{m}$, and a power of $90 \mathrm{~W}$. Design of printable products is performed with the help of free surface modelling programs. Post-processing takes place manually, with hand-operated polishing equipment. 


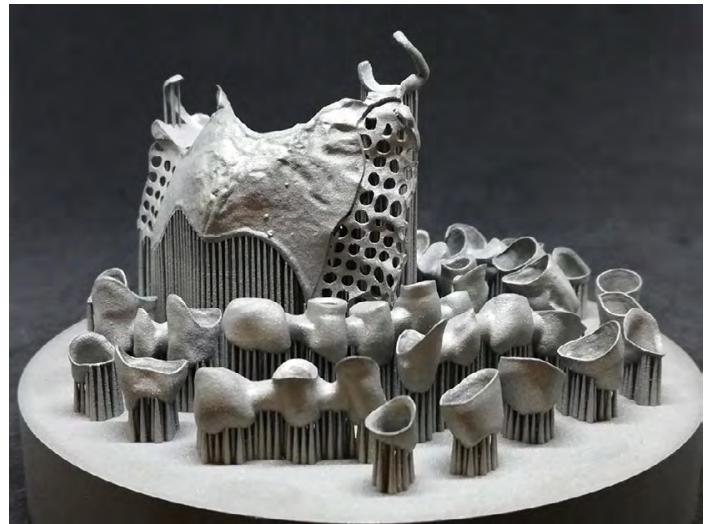

Figure 1. The 3D printing workspace

\section{Fitting requirements of 3D-printed frame structures}

We distinguish between the creations of two significantly different products. The first one represents conventional metal-structure dental prostheses fixed to the refined abutments with adhesive bonding. The other represents fixed, metal-structure prostheses where implants are used as fixation pillars for the prosthesis, and structural integrity is warranted by detachable screw-joints. In the case of the same printing parameters in both products, we can expect the same printing defects. These can be an average geometric defect, surface roughness defect, imprecision due to the support material, and technological defect. Based on manufacturer's data and own measurement experiences, its total extent is under $35 \mu \mathrm{m}[1,4]$.

\subsection{Factors affecting the nesting of ad- hesion-bonded frame structures}

The typical anatomical property of pillar teeth is resilience, which is the elastic nesting in the periodontium allowing 30-50 $\mu \mathrm{m}$ shifting [10]. Another influencing factor is the fixation on pillar teeth, which is generally done with glass ionomer cement with an average grain size of 35$40 \mu \mathrm{m}$ [1]. For this, an 80-100- $\mu \mathrm{m}$-wide adhesion gap is created during the design procedure. The typical extent of imprecision is under $35 \mu \mathrm{m}$ for the 3D-printed frame structure. Because of this, manufacturing imprecision can be eliminated with minimal resilience together with the use of adhesive material [4]. There is no need to calculate using the minimal factors resulting from the elasticity of the frame structure [5].

\subsection{Factors affecting the nesting of screw-fixed implant-pillar frame structures}

The anatomical resilience of implant pillars that is not followed by compression necrosis of surrounding bone tissue is only 7-8 $\mu \mathrm{m}$ [11]. The second affecting factor is the nesting of the fitting surface of 2-piece implants. It can be fixed on a platform or a taper and requires precise, positioned fitting with an average value of less than $5 \mu \mathrm{m}$. Improperly closed implant nesting surfaces can be susceptible to the formation of adverse bacterial flora. It can result in peri-implantitis in the neighbouring tissue and loss of the implant. In this case, elastic deformation, which has an average value of 10-15 $\mu \mathrm{m}$ on peripheries of the complex multi-pillar-supported frame structure also plays an important role [9]. Its evaluation is carried out with Sheffield tests. Refining post-milling of 3D-printed parts is required based on the obtained data [2, 12].

\section{The combined use of additive and subtractive technologies}

The condition of their use is the expanding or offsetting the pre-defined milling surface with a surface allowance. This offsetting procedure is carried out during design in a parametric support program. The designed allowance provides excess material for post-milling process and deviation compensation. In the next step, during the printing platform design, auxiliary units are added to the frame structure model. They are needed for "zero-point" positioning in the milling machine. This modi-fied printing composition is then uploaded to the 3D printing machine. After the printing process, parts are sand-blasted to correct sur-face roughness. Afterwards, heat treatment is carried out with modified parameters. These parameters were determined using data from experiments evaluating the strength and structure of materials. Based on data of former material tests, it was proven that the me-chanical properties of 3D-printed metal struc-tures, heat treated according to the recom-mendations of the manufacturer, can be im-proved to achieve better metal cutting circum-stances. The aim of the heat treatment is to achieve such a modified material structure during stress relieving that is more easily ma-chinable during precision post-processing (Figure 2.).

Four modified heat treatment strategies were defined. [7]. After printing and heat treating of the specimens, tensile and hardness tests were 
performed (Table 1.). Experimental and metallographic data, comparable to our $\mathrm{CoCr}$ alloy, were used. Table 2 . shows the chosen technological parameters of heat treatments measured in a real-life environment in a Nabertherm P330 heat treat furnace.

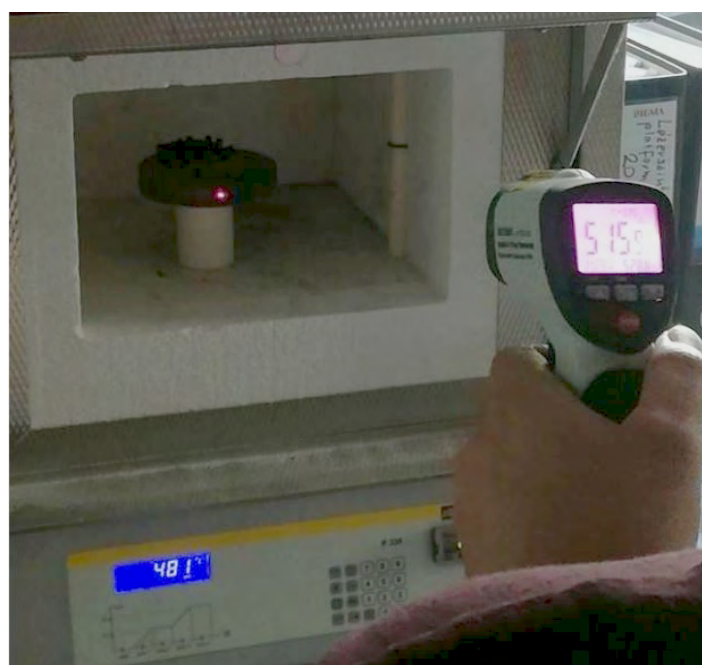

Figure 2. The Nabertherm P330 heat treatment oven during use

Table 1. Mechanical properties of the result

\begin{tabular}{|l|c|c|c|}
\hline & $\begin{array}{c}\text { Yield } \\
\text { strength } \\
\text { (MPa) }\end{array}$ & $\begin{array}{c}\text { Fracture } \\
\text { strain } \\
\text { (\%) }\end{array}$ & $\begin{array}{c}\text { Elastic } \\
\text { modulus } \\
\text { (MPa) }\end{array}$ \\
\hline Manufacturer & 923 & 7.40 & 39180 \\
\hline Modified & 1003 & 16.06 & 33804 \\
\hline
\end{tabular}

Table 2. Heat treatment modification

\begin{tabular}{|l|l|l|l|}
\hline \multicolumn{2}{|c|}{ Heat treatment } & \multicolumn{2}{c|}{ Modified heat treatment } \\
\hline Start temperature & $650^{\circ} \mathrm{C}$ & Start temperature & $650^{\circ} \mathrm{C}$ \\
\hline Heating: $18 \mathrm{~min}$ & $800^{\circ} \mathrm{C}$ & Heating: $38 \mathrm{~min}$ & $900^{\circ} \mathrm{C}$ \\
\hline Heating: $15 \mathrm{~min}$ & $800^{\circ} \mathrm{C}$ & Heating: $28 \mathrm{~min}$ & $900^{\circ} \mathrm{C}$ \\
\hline Cooling: $60 \mathrm{~min}$ & $550^{\circ} \mathrm{C}$ & Cooling: $75 \mathrm{~min}$ & $550{ }^{\circ} \mathrm{C}$ \\
\hline
\end{tabular}

\section{Precision post-processing}

\subsection{Manufacturing unit}

The Vhf S1 simultaneous 5-axis dental milling machine operates a water-cooling system. Thus, it is capable of machining both CoCr and titanium materials. It is characterized by a $0.6 \mathrm{~kW}$ spindle, small dimensions, and a high repeat accuracy of $\pm 0,003 \mathrm{~mm}$.

\subsection{Tools}

The outstanding quality of OSG Dental Industry diamond coating provides an extended application area for tools in dental metal processing [1, 5]. Because of the modified heat treatment parameters, our OSG Dental Industry tools are more durable, and capable of performing the machining protocol in a more tool-saving way (Figure 3. and 4.)

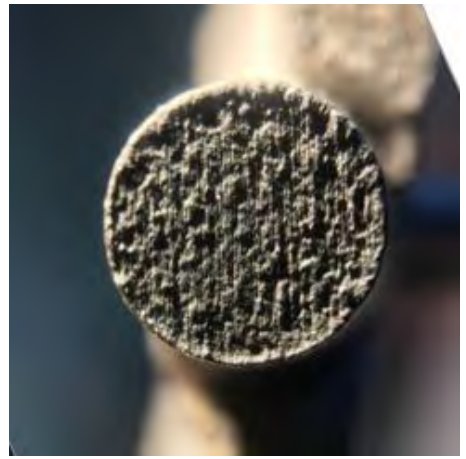

Figure 3. Geometry and surface before postproduction

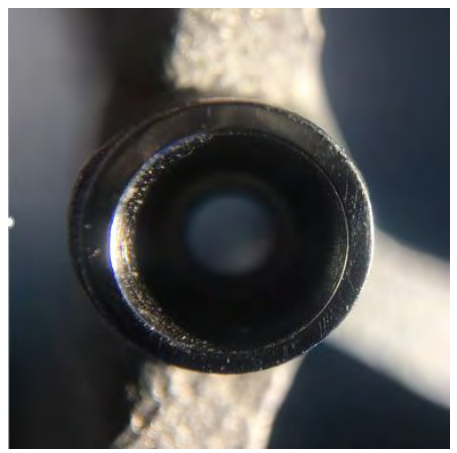

Figure 4. The implanted fitting surface after processing

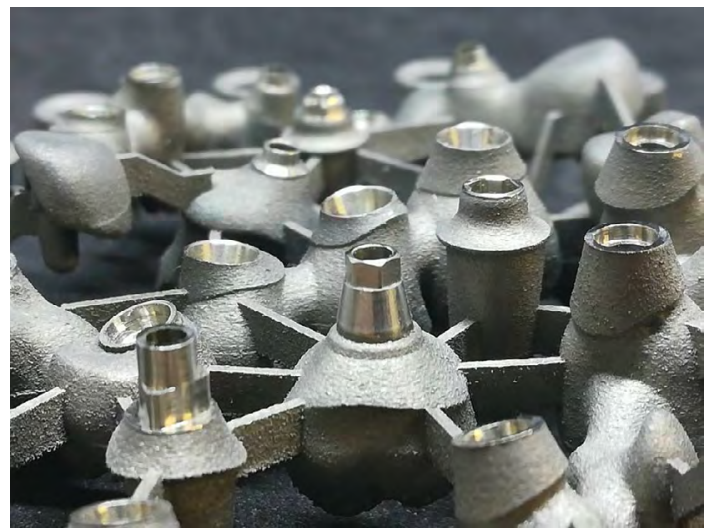

Figure 5. Frame structures of dental restorations with finished contact surfaces 


\section{Summary}

Using the results of heat treatment and the possibility of 3D-printed frame structure post-milling, implant-fixed dental prostheses, which are used in dental technician practice, can be created with the fitting precision as determined in our study (Figure 5.).

\section{References}

[1] Nelson N., K. S. J., Sunny K.: Marginal Accuracy and Internal Fit of Dental Copings Fabricated by Modern Additive and Subtractive Digital Technologies. The European Journal of Prosthodontics and Restorative Dentistry, 25/1. (2017) 20-25. https://doi.org/10.1922/EJPRD_01611Nelson06

[2] Joda T., Ferrari M., Gallucci G. O., Wittneben J. G., Brägger U.: Digital technology in fixed implant prosthodontics. Periodontol 2000, 73/1. (2017) 178-192. https://doi.org/10.1111/prd.12164

[3] Kim K. B., Kim J. H., Kim W. C., Kim J. H.: Three-dimensional evaluation of gaps associated with fixed dental prostheses fabricated with new technologies. The Journal of Prosthetic Dentistry, 112/6. (2014) 1432-1436. https://doi.org/10.1016/j.prosdent.2014.07.002

[4] van Noort R.: The future of dental devices is digital. Dental Materials, 28/1. (2012) 3-12. https://doi.org/10.1016/j.dental.2011.10.014

[5] Kim D. Y., Kim J. H., Kim H. Y., Kim W. C.: Comparison and evaluation of marginal and internal gaps in cobalt-chromium alloy copings fabricated using subtractive and additive manufacturing. Journal of Prosthodontic Research, 62/1. (2018) 56-64. https://doi.org/10.1016/j.jpor.2017.05.008
[6] Yan X., Lin H.: Research progress in CoCr metal-ceramic alloy fabricated by selective laser melting. Zhonghua Kou Qiang Yi Xue Za Zhi, 53/2. (2018) 141-144.

https://doi.org/10.3760/cma.j.issn.1002-0098. 2018.02.017

[7] Barazanchi A., Li K. C., Al-Amleh B., Lyons K., Waddell J. N.: Additive Technology: Update on Current Materials and Applications in Dentistry. Journal of Prosthodontics, 26/2. (2017) 156-163. https://doi.org/10.1111/jopr.12510

[8] Kassapidou M., Franke Stenport V., Hjalmarsson L., Johansson C. B.: Cobalt-chromium alloys in fixed prosthodontics in Sweden. Acta Biomaterialia Odontologica Scandinavica, 3/1. (2017) 53-62. https://doi.org/10.1080/23337931.2017.1360776

[9] de França D. G., Morais M. H., das Neves F. D., Carreiro A. F., Barbosa G. A.: Precision Fit of Screw-Retained Implant-Supported Fixed Dental Prostheses Fabricated by CAD/CAM, Copy-Milling, and Conventional Methods. The International Journal of Oral \& Maxillofac Implants, 32/3. (2017) 507-513. https://doi.org/10.11607/jomi.5023

[10] Fehér E., Gallatz K., Gerber G., Székely A. D.: $M a-$ xillofacialis anatómia. Medicina Könyvkiadó Zrt., Budapest, 2014. 79-9.

[11] Ihde S. K. A., Ihde A. A.: Bevezetés a Stratégiai Implantátumok használatába. International Implant Foundation Publishing, München, 2016.

[12] Marková K., Mitrushchenkov Y., Idhe S. K. A., Idhe A. A.: Stratégiai implantátumokon végzett technikai munkafázisok. International Implant Foundation Publishing, München, 2016.

[13] Redwood B., Schöffer F., Garret B., The 3D Printing Handbook. 3D Hubs B.V., Amsterdam, 2017. 123-133, 213-215. 